\title{
Endodontic Treatment in a single session in a patient with Chronic Non-Progressive Encephalopathy: Case report
}

Tratamento Endodôntico em sessão única em paciente com Encefalopatia Crônica Não

Progressiva: Relato de caso

Tratamiento Endodóntico en una sola sesión en un Paciente Crónico No Progresivo: Reporte de caso

Received: 04/29/2021 | Reviewed: 05/05/2021 | Accept: 05/10/2021 | Published: 05/26/2021

Victoria Eduarda Vasconcelos Liberato Miranda ORCID: https://orcid.org/0000-0002-1025-1503 Universidade de Pernambuco, Brazil E-mail: eduardavvl@hotmail.com

Zayne Barros da Silva

ORCID: https://orcid.org/0000-0003-4154-4381 Centro Odontológico de Estudos e Pesquisas, Brazil E-mail: barros.zay@gmail.com

Davi Silva Carvalho Curi ORCID: https://orcid.org/0000-0001-6471-9071 Centro Odontológico de Estudos e Pesquisas, Brazil

E-mail: curidavi@gmail.com

Milcyara Cunha de Lucena Bem ORCID: https://orcid.org/0000-0003-4094-800X Centro Odontológico de Estudos e Pesquisas, Brazil E-mail: milcyaralucena@hotmail.com

Valdenice Aparecida de Menezes ORCID: https://orcid.org/0000-0003-4183-3239 Universidade de Pernambuco, Brazil E-mail: valdmenezes@hotmail.com

Adriana Gledys Zink

ORCID: https://orcid.org/0000-0001-7005-5689 Centro Odontológico de Estudos e Pesquisas, Brazil E-mail: zinkpinho@yahoo.com.br

\begin{abstract}
This study aims to report a one-session endodontic treatment of a patient with chronic Non-progressive encephalopathy (CNPE). A patient with CNPE attended our postgraduate clinic for patients with special needs. During the anamnesis, the patient's brother, who is his legal representative, reported discomfort with the esthetics of the patient's anterior tooth and that the patient felt discomfort when touching the same dental element. After detailed anamnesis and elaboration of the treatment plan, endodontic treatment of element 11 (upper right central incisor) and coronary reconstruction were performed. Taking care of patients with cerebral palsy is still a challenge in dentistry. This is because care has to be taken when carrying out necessary interventions in these patients. This treatment aims at the positive resolution of their pathological condition and well-being. The possibility of endodontic treatment in a single session makes treatment more humane and less mutilating.
\end{abstract}

Keywords: Cerebral palsy; Oral diagnosis; Endodontics.

\section{Resumo}

Esse estudo objetiva relatar o tratamento endodôntico de uma sessão em paciente com encefalopatia não progressiva crônica (CNPE). Um paciente com CNPE atendeu nossa clínica de pós-graduação para pacientes com necessidades especiais. Durante a anamnese, o irmão do paciente, que é seu representante legal, relatou desconforto com a estética do dente anterior do paciente e que o paciente sentia desconforto ao tocar o mesmo elemento dentário. Após detalhada anamnese e elaboração do plano de tratamento, foi realizado tratamento endodôntico do elemento 11 (incisivo central superior direito) e reconstrução coronariana. $\mathrm{O}$ atendimento ao paciente com paralisia cerebral ainda é um desafio na Odontologia. Isso ocorre porque é preciso ter cuidado ao realizar as intervenções necessárias nesses pacientes. Este tratamento visa a resolução positiva do seu estado patológico e bem-estar. A possibilidade de tratamento endodôntico em uma única sessão torna o tratamento mais humano e menos mutilador.

Palavras-chave: Paralisia cerebral; Diagnóstico oral; Endodontia. 


\section{Resumen}

Este trabajo tiene como objetivo informar sobre un tratamiento endodóntico de una sesión de un paciente con encefalopatía crónica no progresiva (CNPE). Un paciente con CNPE acudió a nuestra clínica de posgrado para pacientes con necesidades especiales. Durante la anamnesis, el hermano del paciente, quien es su representante legal, refirió malestar con la estética del diente anterior del paciente y que el paciente sintió malestar al tocar el mismo elemento dental. Tras una anamnesis detallada y elaboración del plan de tratamiento, se realizó tratamiento endodóntico del elemento 11 (incisivo central superior derecho) y reconstrucción coronaria. La atención al paciente con parálisis cerebral aún es un desafío en la Odontología. Esto se debe a que hay que tener cuidado al realizar las intervenciones necesarias en estos pacientes. Este tratamiento tiene como objetivo la resolución positiva de su estado patológico y su bienestar. La posibilidad de un tratamiento de endodoncia en una sola sesión hace que el tratamiento sea más humano y menos mutilador.

Palabras clave: Paralisia cerebral; Diagnóstico oral; Endodoncia.

\section{Introduction}

Chronic Non-Progressive Encephalopathy - CNPE, also called Cerebral Palsy - CP, is part of a group of nonprogressive disorders resulting from maturing brain injury. It is described as a set of postural and movement disorders that leads to functional limitation of the child (Abanto, 2009). It is one of the most frequent and important neurological problems that occur in the brain development phase in children. The etiology of CNPE is multifactorial and can be triggered in the pre, peri, or post-natal periods (Amado et al., 2013).

The clinical picture of the patient with this pathology is characterized by motor and postural abnormalities and changes in muscle tone, such that a voluntary movement that is usually complex, coordinated, and varied becomes uncoordinated, stereotyped, and limited (Amaral \& Mazzitelli, 2003).

Poor oral hygiene is common in these patients due to the lack of ability to brush (Burkhard, 2013). Thus, people with CNPE usually depend on others to perform their oral hygiene. A higher prevalence of carious lesions is also common in these patients. This is closely associated with the high frequency of consumption of a pasty and carbohydrate-rich diet, with a masticatory chew between the back of the tongue and the palate, and with a lack of coordination of the masticatory muscles (Castro et al., 2010). The presence of food residues on the palate and tongue is very common (Clemetson et al., 2012), in addition to the poor oral hygiene described previously. Therefore, the patient often comes to the dental office with multiple needs.

The objective of this work was to point out, through a clinical case report, the importance of treatment and dental follow-up of patients with CNPE which directly interferes with the quality of life and good prognosis of the patient's entire oral and systemic condition.

\section{Methodology}

A CVN patient, 29 years old, female, and clinically diagnosis with CNPE, attended the postgraduate dental clinic for dental treatment. During the anamnesis, the patient's brother, who is her legal representative, and the sister reported discomfort with the esthetics of the patient's anterior tooth, claiming it was broken and blackened. In addition, it was observed by the guardians that the patient felt uncomfortable when touching the same dental element. In the extra-oral clinical examination, facial asymmetry, lack of lip seal, muscle hypotonia, and some moments of spasms in the facial musculature were observed (Figure 1A). On intraoral clinical examination, dental element 11 (upper right central incisor) presented with a deep cavity and a possible pulp exposure.

Imaging examination showed a radiolucent image suggestive of caries with extension into the pulp without the presence of a periapical lesion (Figure 1B, 1C, AND 1D). Due to the extent of the lesion and radiological evaluation, the treatment of choice was endodontic treatment under local anesthesia in an outpatient setting. 
In accordance with resolution 466/12 of the National Health Council, regarding studies with human beings, a Free and Informed Consent Term (ICF) was created, containing all information about the proposed treatment and the possible possibility of using the clinical case. in scientific publication. The Informed Consent Form (ICF) was signed before the beginning of treatment by the person responsible for the patient. The document was written in order to provide an understanding of care in a school clinic and its implications for the research subjects.

Figure 1. Clinical evaluation.

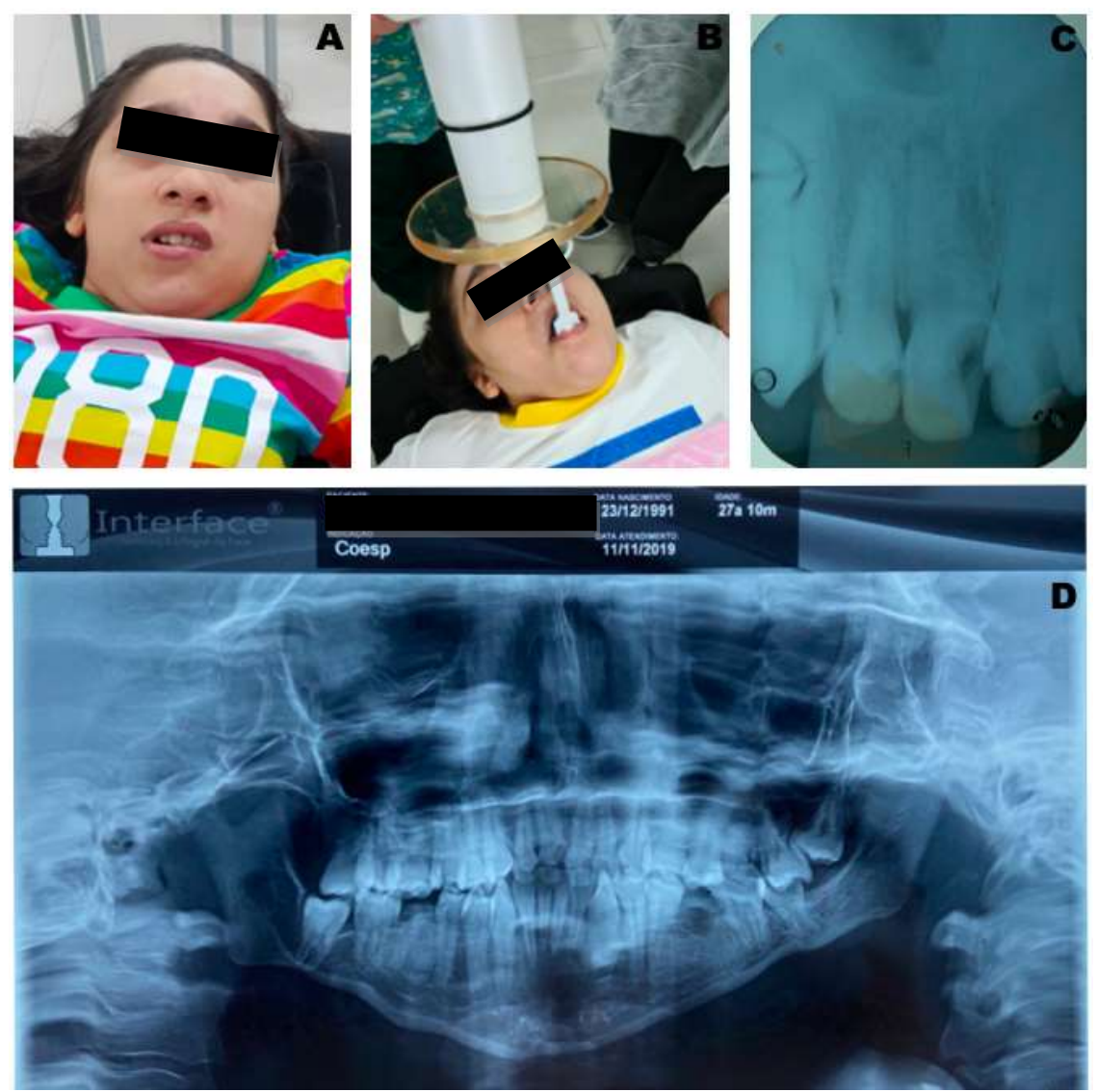

\footnotetext{
Legend:

A) extra-oral examination: facial asymmetry, lack of lip seal and muscle hypotonia.

B) radiological evaluation with portable $x$-ray.

C) periapical radiography showing a radiolucent image, suggestive of caries with pulp extension.

D) panoramic radiography of the patient.

source: authors.
}

First, the brothers read and agreed to the free and informed consent terms authorizing the service, as well as taking photos and disseminating them for scientific work. Dental care was conducted in the patient's chair since it provided comfort and a good positioning for the clinical procedure. The chair is tailored to the needs of this patient.

All endodontic treatment were performed in a single session followed by restoration of the dental element (Figure 2A). Initially, subperiosteal anesthesia plus infiltrative anesthesia was performed with Mepivacaine $2 \%$ (Mepiadri®) with 1 a 100,000 vesselconstrictor.

Absolute isolation was performed with clamp 210, rubber sheet, and Ostby arch, with continuous monitoring of Oxygen saturation using a finger oximeter (Figure 2B). The treatment continued and the pulp tissue was removed with a Hedstroen \# 15 file and irrigation with $5 \mathrm{~mL}$ of $2.5 \%$ sodium hypochlorite ( $\mathrm{NaClO}$ ). The Gates \# 2 drill was used to widen the canal entrance. Dentometry was performed with the use of an electronic foraminal locator with the K \# 15 Flex file. At that time, a periapical radiography was performed with a portable X-ray machine to facilitate taking since the treatment was being 
carried out on the patient's wheelchair thus accessing the X-ray room was difficult. Manual instrumentation was performed with file type $\mathrm{K}$ until file \# 25, and then the use of the rotary drill Protaper® system following the sequence: purple, white, yellow, red, and blue. At each change of drills in the Protaper ${ }^{\circledR}$ system, the EndoPTC was used to lubricate the drills and the canal was cleaned. Irrigation was carried out with $2 \mathrm{~mL}$ of $2.5 \% \mathrm{NaClO}$ at each drill (Figure $2 \mathrm{C}$ and 2D).

Figure 2. Dental clinic care.
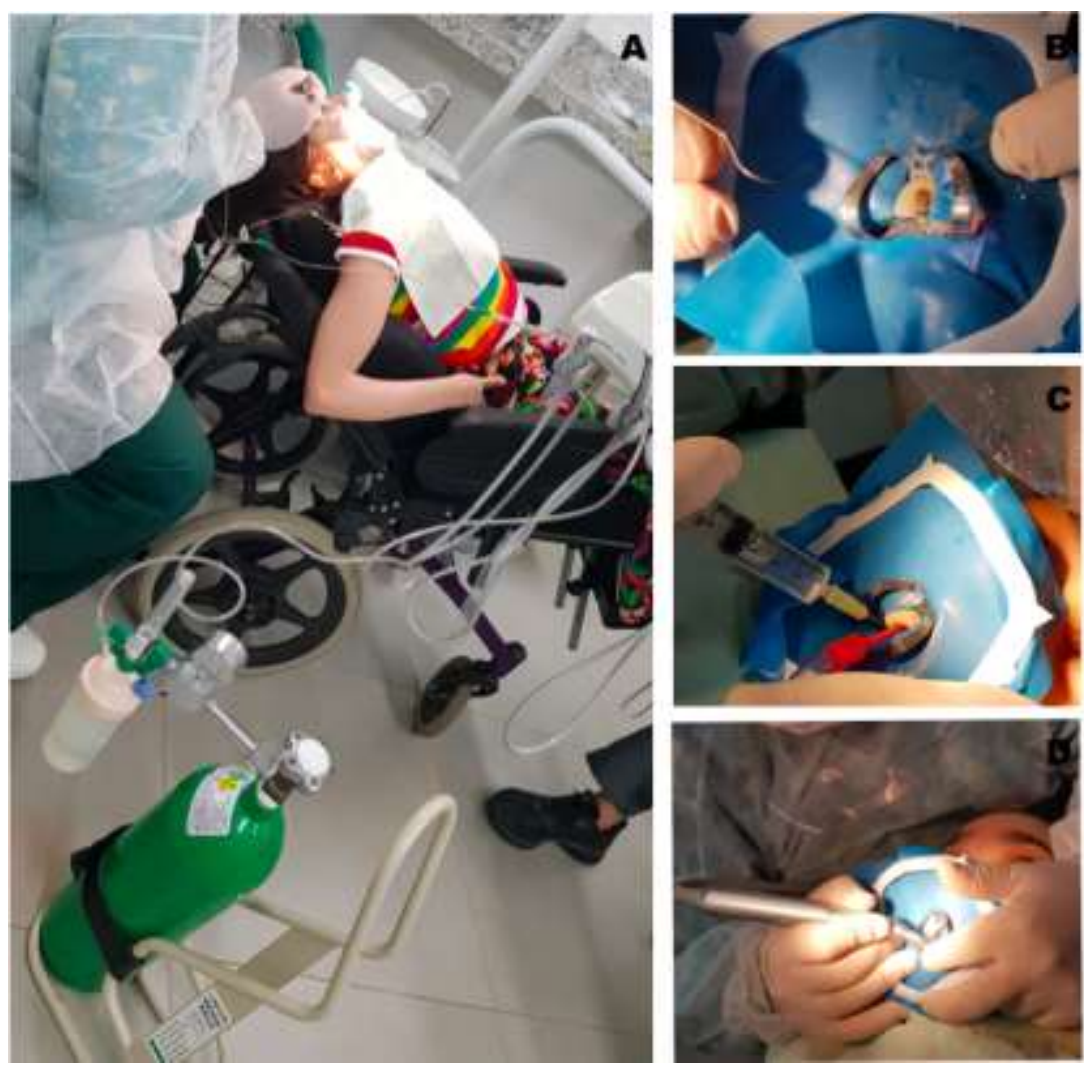

Legend:

A) Dental care was conducted in the patient's chair.

B) Absolute isolation was performed.

C) Irrigation was carried out with $2.5 \%$ Sodium Hypochlorite $(\mathrm{NaClO})$.

D) The use of rotary drills Protaper® system following the sequence: purple, white, yellow, red and blue.

Source: Authors.

After the mechanical and chemical Preparation described above, irrigation was performed with 0.9 saline solution and endodontic aspiration was performed. Irrigation with Edta Trisodium was then followed by serum solution to remove the excess EDTA. Once the cone was tested, with the Protaper® System F3 cone, plus a periapical radiography of the socket was carried out to verify the correct positioning of the main cone.

To complete the procedure, a final irrigation was carried out with $0.9 \%$ saline and dried by aspiration and with the absorbent paper cone followed by cementation of the F3 cone with Fillapex MTA cement. The cone cutting and radicular sealing with Riva Self Cure glass ionomer were performed before the final x-ray.

The entire process was monitored with the aid of a finger oximeter. During the procedure, there was a moment of desaturation where the use of oxygen was necessary using a nasal catheter. After a few minutes of exposure to oxygen, the patient evolved to normal saturation patterns. We opted to maintain oxygen support until the end of the session (Figure 3A, 3B, 3C, and 3D). 
Figure 3. Monitoring of oxygen saturation.
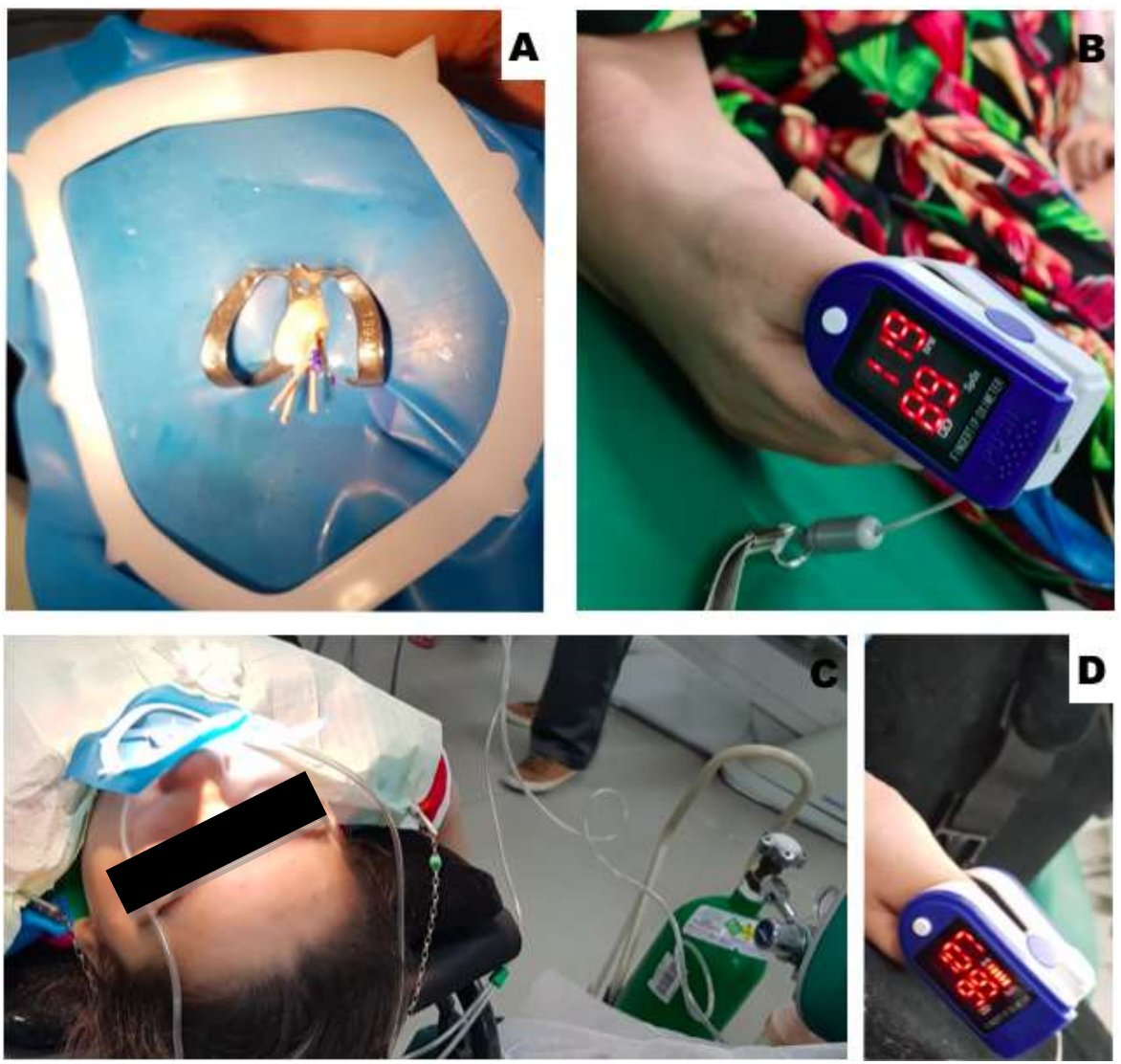

Legend:

A) Filling the canal with F3 cone and Fillapex MTA cement.

B) Moment of desaturation.

C) Oxygen with a nasal catheter support until the end of the session.

D) Normal saturation

Source: Authors.

The crown reconstruction was done in the same session, starting with cleaning the cavity and conditioning with $37.5 \%$ phosphoric acid on the remaining surface of the tooth structure for 30 seconds. After washing and drying, Stae SDI adhesive was applied. There was some difficulty in placing the matrix and wooden wedge.

The photo-activated composite resin Charisma OA3 Kulzer was used. The absolute isolation was removed, and the occlusal adjustment was made with carbon and diamond and multi-laminated drills. Polishing was performed with a Sof-lex sanding disc, abrasive rubber tips, and filled with a polishing paste.

Radiographic shots were taken at the end of the endodontic treatment and after 3 months for postoperative observation and follow-up (Figure 4A, 4B, 4C, and 4D). 
Figure 4. Procedures Performed.

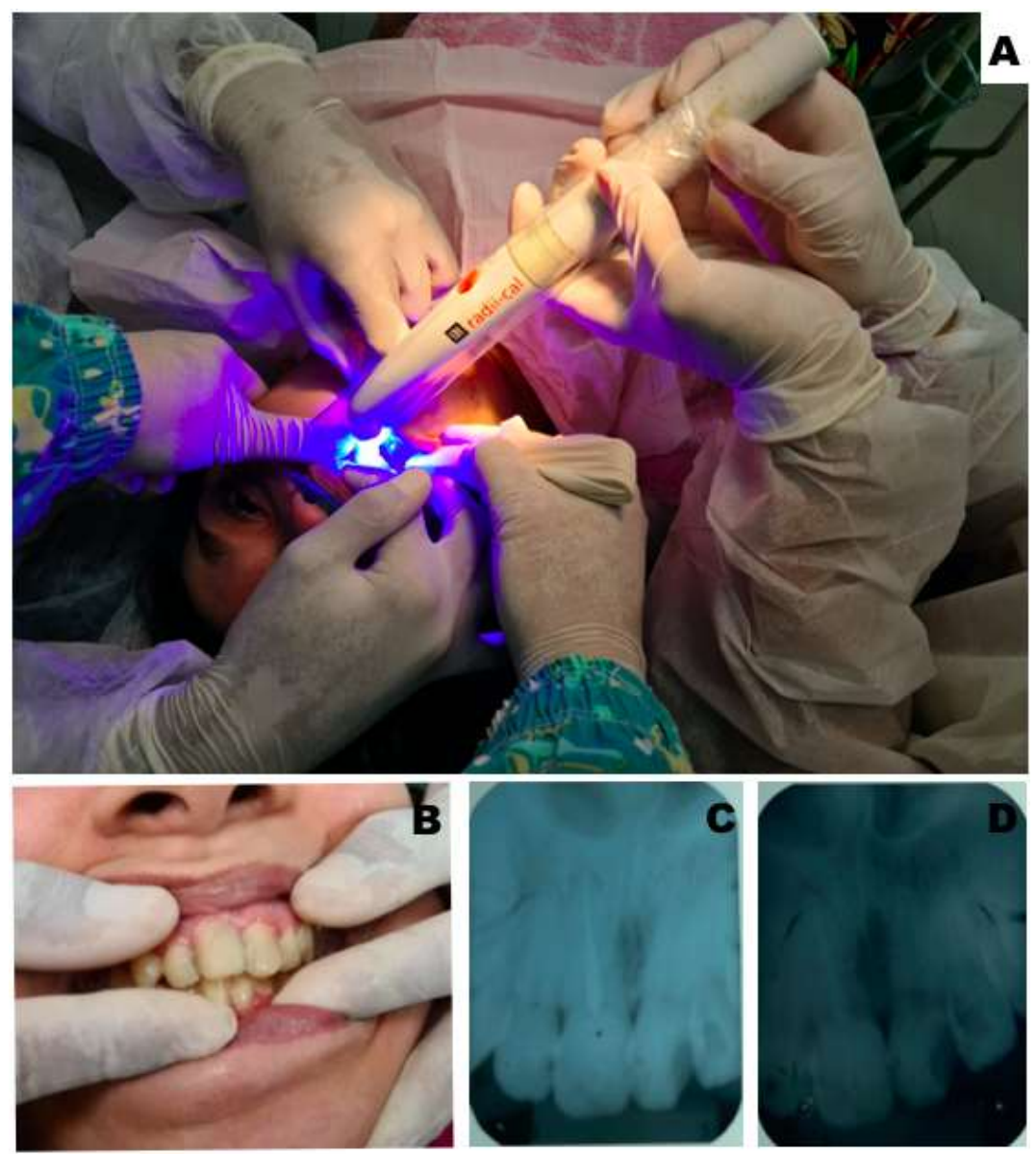

Legend:

A)Photo activated composite resin Charisma OA3 Kulzer was used.

B)Coronary reconstruction was performed.

C)Periapical radiography was taken at the end of the endodontic treatment.

D)Periapical radiography was taken after 3 months.

Source: Authors.

\section{Results and Discussion}

Patients with CP require individualized and humanized dental care. It is essential to build a relationship of trust between the dentist and the patient and, even more, between the professional and the caregivers. The dental care of this group of people must be prioritized and requires multidisciplinarity. For these patients seeking dental care, the promotion of oral health, and maintenance must be ensured (Katz, 2012; Krigger, 2006).

Another inherent factor present in the life of a patient with cerebral palsy and his family is the psychological stress. It distances the patient further from the dental clinic, coupled with the low priority given to oral health by the family due to the various other health problems presented.

The inability of these patients to communicate clearly and to be able to inform their caregivers about any oral or dental discomfort can also be a reason for the low demand for preventive and curative dental care (Leite \& Prado, 2014).

In this reported clinical case, the intervention had to be more invasive due to the clinical condition presented by the dental element. Endodontic treatment was performed in a single session.

Currently, endodontic treatment in a single session has been increasingly recommended by endodontists because of its speed and efficiency in solving the problem. The modeling of the ducts and the biomechanical preparation carried out by the 
files and the irrigation solution in a single session has shown satisfactory results in relation to the technique. With the help of technology currently available on the market, such as apex locators, digital sensors, and rotary instruments, it is possible to significantly reduce the time of the endodontic sessions (Ludke \& Andre, 2013).

Endodontic instrumentation must be effective in removing the root canal debris or the root pulp. Irrigation solutions, on the other hand, play an important role through chemical means, to act both in the main canal and in the secondary canal (MacLennan et al., 2015). Another relevant factor to be considered in endodontic treatment is postoperative pain.

Knowledge of the anatomy of the root canals, preparation techniques, and filling will minimize the chances of postoperative pain. A well-prepared preparation will induce a low-intensity inflammatory response (Msall \& Park, 2008).

Therefore, endodontic treatment in a single session helps minimizes time from clinical sessions for the dentist and the patient. Also helps to reduct the discomfort of a multi-session treatment. This is possible through a range of modern accessories available in the market that facilitate treatment.

\section{Conclusion}

The quality of life of patients is significantly improved when it is possible to keep teeth in the oral cavity. The impact on oral health is considered positive when none or the fewest teeth are extracted during treatment (Marcos et al., 2015).

This implies that the functional and psychological benefits of maintaining teeth should not be underestimated for patients with special needs and their caregivers, even if their severe deficiencies are obstacles in the performance of conventional treatments.

The treatment aims at the positive resolution of their pathological condition and well-being. The possibility of endodontic treatment in a single session makes treatment more humane and less mutilating.

\section{References}

Abanto, J. (2009). Avaliação dos hábitos alimentares de interesse odontológico em crianças com paralisia cerebral. Rev Inst Ciência Saúde, 27(1), 244-248.

Amado, D. D. A. D., Pacheco, R., Faria, R. A., Oliveira, M. A. V. C., Caram, C. M., Georhutti, R. P., \& Amado Jr, F. (2013). Tratamento endodôntico em sessão única com uso de lima. Reciproc: Relato de caso. [Monografia]. Uberlândia.

Amaral, P. P., \& Mazzitelli, C. (2003). Alterações ortopédicas em crianças com paralisia cerebral da clínica-escola de Fisioterapia da Universidade Metodista de São Paulo. Rev Neurocienc. 11(1), 29-33.

Burkhard, A. (2013). A different life: caring for an adolescent or young adult with severe cerebral palsy. J Pediatr Nur. 28(4), $357-363$.

Castro, A. L., Marchesoti, M. G. N., Oliveira, F. S., \& Novaes, M. S. P. (2010). Avaliação do tratamento odontológico de pacientes com necessidades especiais sob anestesia geral. Rev Odonto UNESP. 39, 137-142.

Clemetson, J. C., Jones, D. L., Lacy, E. S., Hal, D., \& Bolin, K. A. (2012) Preparing dental students to treat patients with special needs: changes in predoctoral education after the revised accreditation standard. J Dent Educ. 76, 1457-1465.

Katz, C. R. (2012). Integrated approach to outpatient dental treatment of a patient with cerebral palsy: a case report. Spec Care Dentist. 32 , $210-217$.

Koche, J. C. (2011). Fundamentos de metodologia científica. Vozes.

Krigger, K. W. (2006). Cerebral palsy: an overview. Am Family Phys. 73(1), 91-100.

Leite, J. M. R. S., \& Prado, G. F. (2014). Paralisia cerebral: aspectos fisioterapêuticos e clínicos. Rev Neurocienc. 12(1), 41-50.

Ludke, M. \& Andre, M. E. D. A. (2013). Pesquisas em educação: uma abordagem qualitativa. E.P.U.

MacLennan, A. H., Thompson, S. C., \& Gecz, J. (2015). Cerebral palsy: causes, pathways, and the role of genetic variants. Am J. Obstet Gynecol. 213(6), 779788 .

Marcos, S. E., Ana Clara, L. S., Angelo, J. P., Alfredo, F. Q., \& Nair, N. O. P. (2015). Endodontia em sessão única ou múltipla: revisão da literatura. RFO. 20(3), 408-413.

Msall, M. E., \& Park, J. J. (2008). Neurodevelopmental management strategies for children with cerebral palsy: optimizing function, promoting participation, and supporting families. Clin Obstet Gynecol. 51(4), 800-815. 
Research, Society and Development, v. 10, n. 6, e16610615598, 2021 (CC BY 4.0) | ISSN 2525-3409 | DOI: http://dx.doi.org/10.33448/rsd-v10i6.15598

O'Shea, T. M. (2008). Diagnosis, treatment and prevention of cerebral palsy in near-term/term infants. Clin Obstet Gynecol. Dec, 51(4), 816-828.

Pereira, A. S. et al. (2018). Metodologia da pesquisa cientifica. UFSM. https://repositorio.ufsm.br/bitstream/handle/1/15824/Lic_Computacao_MetodologiaPesquisa-Cientifica.pdf?sequence $=1$.

Reddihough, D. S, \& Collins, K. J. (2003). The epidemiology and causes of cerebral palsy. Aust J Physiother. 49, 7-12.

Resende, V. L. S., Castilho, L. S., Viegas, C. M. S., \& Soares, M. A. (2007). Fatores de risco para a cárie em dentes decíduos de portadores de necessidades especiais. Pesq Bras Odontoped Integr. 7, 111-117.

Rosenbaum, P., Paneth, N., Leviton, A., Goldstein, M., \& Bax, M. (2007). The definition and classification of cerebral palsy. Dev Med Child Neurol. Feb, 49, Suppl 109, 1-44.

Rotta, N. T. (2012). Paralisia cerebral: novas perspectivas terapêuticas. J Pediatr. 78(1), 48-54.

Santos, A. T. L., \& Couto, G. B. L. (2008). Atendimento odontológico ao paciente portador de paralisia cerebral. Int J Den. 7, $133-141$.

Stegbauer, C. C. (1996). Parent's opinions concerning possible causes of cerebral palsy. Nurse Practitioner. 21(4), 116-196.

Symanski, N. C. (2015). Terapia endodôntica: sessão única x sessão múltipla. Faculdade de Odontologia do Rio Grande do Sul.

Yin, R. K. (2015). O estudo de caso. Bookman. 